\title{
História, política e testemunho: violência e trabalho na Amazônia brasileira. A narrativa oral da presidenta do Sindicato dos Trabalhadores Rurais de Confresa (MT), Aparecida Barbosa da Silva
}

\author{
Regina Beatriz Guimarães Neto*
}

Aqui o filho chora e a mãe não vê... (ditado popular citado por Aparecida Barbosa da Silva)

O tema de maior interesse deste $\operatorname{artigo}^{1}$ é a expressão política e cultural que assume a narrativa oral de Aparecida Barbosa da Silva, presidenta do

* Professora do Departamento e do Programa de Pós-Graduação em História da Universidade Federal de Pernambuco (UFPE). Pesquisadora do CNPq. Dedico este texto a Aparecida Barbosa da Silva. Sua generosidade, confiança e coragem ao conceder-me as entrevistas, inestimáveis, tornaram este texto e outras experiências possíveis. Minha gratidão é inseparável da amizade e admiração que por ela tenho. Aos estudantes dos cursos de História das Parceladas/Unemat, no Araguaia, que comigo também partilharam suas histórias de vida, sou imensamente grata.

1 Este texto integra um projeto de pesquisa que foi contemplado com bolsa produtividade pelo Conselho Nacional de Desenvolvimento Científico e Tecnológico (CNPq); e, ainda, está associado a um projeto que reúne um conjunto de textos a ser publicado em um livro acerca do tema do trabalho, com base nos relatos orais e escritos de diversos atores sociais, especialmente, aqueles envolvidos com a experiência designada como "trabalho análogo a de escravo", no mundo contemporâneo, em parceria com a historiadora Angela de Castro Gomes (UFF/CPDOC/FGV - Rio de Janeiro). Agradeço a Angela a riqueza de suas contribuições e novas possibilidades de análises que se abrem com a sua participação nessa pesquisa, especialmente, o debate teórico e metodológico acerca do trabalho "análogo a de escravo". E de sua amizade, sempre, bem maior. Quero, também, agradecer aqui a valiosa leitura crítica de Antônio Montenegro a este texto, que o tornou melhor, e, ainda comigo, participou de forma solidária e comprometida com a experiência de ensino e pesquisa no Araguaia, no Projeto Parceladas/Unemat. Sou grata, ainda, às contribuições e sugestões de Vera Acioli e Airton dos Reis Pereira. 
Sindicato dos Trabalhadores Rurais do município de Confresa (MT). ${ }^{2}$ Nascida em 1953 no estado de Goiás, sua família, como tantas outras, segue em direção à parte norte do estado de Mato Grosso, na década de 1990; ali vivencia uma situação de conflito pela terra, numa área de posse, no município de Ribeirão Cascalheira - onde inicia sua dura aprendizagem para reivindicar os seus direitos -, até se estabelecer em uma área de assentamento rural em Confresa, 1997, em negociação com o Instituto Nacional de Colonização e Reforma Agrária (Incra). Começa a exercer sua liderança em defesa dos direitos dos trabalhadores ao assumir posições que a colocam num confronto face a face com os proprietários rurais/donos de empresas nacionais e multinacionais que comandam o agronegócio exportador naquela área do estado.

Espaço de disputa histórica entre posseiros e fazendeiros, essa é uma das áreas de Mato Grosso de maior incidência de conflitos entre trabalhadores rurais e proprietários de terra, estado que, juntamente com o Pará, Tocantins, Goiás e Maranhão encontra-se, ainda, entre aqueles que apresentam os maiores índices de utilização de trabalho análogo a de escravo no Brasil, segundo dados da Comissão Pastoral da Terra (CPT). ${ }^{3}$ Práticas comuns de grande exploração de mão de obra no campo, trabalho compulsório de vários matizes, aproximam esses estados, que fazem parte do que se convencionou chamar de Amazônia Legal, ${ }^{4}$ e os constituem como um verdadeiro território do "trabalho escravo contemporâneo" (designação do órgão das Nações Unidas para esse assunto), interconectado a amplas redes que se estendem a outras regiões

2 Este município está situado na parte nordeste do estado de Mato Grosso, já nos limites com o Pará, território compreendido na Amazônia Legal. É resultado de um projeto de colonização, da empresa Confresa, que não conseguiu realizar integralmente a venda dos lotes de terra, pois teve a sua área ocupada por diversos segmentos de trabalhadores rurais sem terra. Contudo, cidade/núcleo de colonização que se comunica territorialmente com grandes propriedades por todos os lados, a população que aí se estabeleceu conheceu vários confrontos armados, sobretudo nas áreas que depois vão se transformar em assentamentos agrários. Ver Ferreira, Fernández e Silva (1999), Barrozo (2009), Guimarães Neto (2006).

3 Ver as publicações anuais dos Cadernos Conflitos no Campo no site da Comissão Pastoral da Terra: http://www.cptnacional.org.br.

4 Por meio de um dispositivo legal, a lei 1.806 de 06/01/1953, a Amazônia brasileira passou a ser denominada de Amazônia Legal, criada pelo Plano de Valorização Econômica da Amazônia (sob a coordenação da SPVEA). Integra os estados do Acre, Amapá, Amazonas, Mato Grosso, Pará, Rondônia, Roraima, Tocantins e parte do Maranhão (oeste do meridiano $44^{\circ}$ ). Ao fazer referência ao território amazônico, as análises neste texto operam com a representação de território na perspectiva das práticas sociais e sua dimensão cultural, o que permite pensar o território em seu papel ativo. Ver, especialmente, PortoGonçalves (2001) e Santos (1996). Há uma urgência que se torna impositiva nos estudos que focalizam a Amazônia: uma leitura crítica dos esquemas interpretativos que tem como objetivo explicá-la, identificá-la. Consultar o texto do antropólogo Almeida (2008). 
brasileiras. A denominação, "trabalho análogo a de escravo", que consta no Código Penal brasileiro (art. 149), suscita inúmeras controvérsias e expressa a dimensão de uma disputa política, que tem, desde a década de 1970, no bispo católico Pedro Casaldáliga (1971) de São Félix do Araguaia uma voz de denúncia inexpugnável, ancorada em açôes legitimadoras. Essa disputa se trava em um confronto direto, especialmente, entre os movimentos sociais organizados e comprometidos com a luta pelos direitos humanos - entidades como a CPT, os sindicatos dos trabalhadores rurais - e os grandes e médios produtores rurais, com suas bases de sustentação legais e não legais. É de fundamental importância o reconhecimento e o combate legal e político ao trabalho análogo a de escravo, empreendido pelos poderes judiciário e executivo, sobretudo, após meados da década de 1990, por meio das ações desencadeadas pelos magistrados da Justiça Federal e da Justiça do Trabalho e dos procuradores do Ministério Público do Trabalho (MPT) e do Ministério do Trabalho e Emprego. Ganha cada vez mais notoriedade e legitimidade a prática da fiscalização e autuação daqueles que infringem a lei (estipulada pelo Código Penal), destacando-se o papel dos auditores fiscais nas perigosas ações de fiscalizar in loco as denúncias, contando ainda com a participação imprescindível da Polícia Federal. ${ }^{5}$

A historiadora Angela de Castro Gomes, com uma vasta experiência de pesquisa no campo da historiografia, privilegia a questão do trabalho e da legislação trabalhista no Brasil, no século XX, com vários livros e artigos publicados, em especial $A$ invenção do trabalhismo (Gomes, 2005), que analisa práticas de trabalho análogo a de escravo, no contexto histórico contemporâneo, e contribui com um debate inovador acerca dessa designação conceitual. Entre as questões que aponta em seu artigo (Gomes, 2008, p. 12, 21), uma das mais importantes é a que procura compreender porque a sociedade civil, vista pelos seus diversos grupos atuantes ou ligados aos movimentos sociais, a organizações não governamentais, a entidades como a CPT, entre outras, em defesa dos direitos humanos, mobiliza e legitima a denominação de "trabalho escravo":

Assim, a proposta [...] é compreender o fenômeno social designado como trabalho análogo a de escravo como um fato novo da história recente do

5 Ver a contribuição de Angela de Castro Gomes (2008) para uma avaliação desse quadro político-jurídico e consultar os resultados de uma ampla pesquisa (Pronex), sob sua coordenação, Direitos e cidadania (Gomes, 2007a). Desenvolveu, ainda, em parceria com Elina Pessanha, entre outros trabalhos, uma pesquisa sobre a magistratura do trabalho no Brasil (Gomes, Pessanha, 2010). 
Brasil que, se de um lado tem relações com práticas seculares de exploração do trabalhador, de outro possui singularidades próprias ao contexto das últimas quatro décadas de sua emergência e disseminação. [...] é fundamental observar que há atores e interesses envolvidos no processo de escolha de tal designação, que, como indiquei, embora estivesse no artigo 149 do Código Penal desde 1940, não causava grande espécie no meio acadêmico, nem mobilizava políticas públicas ou ações de organizações não governamentais nacionais e internacionais. [...] é possível afirmar que a questão não é tanto a existência do vocabulário tout court, mas a dos sentidos, a da abrangência, além da força política que ganha, o que, sem dúvida foi produto da intervenção de um conjunto de atores sociais após os anos de 1970.

A questão social do trabalho escravo no Brasil contemporâneo toma, assim, força política como objeto de análise, sobretudo para historiadores, que apresentam uma produção intelectual, de modo geral, mais recente, ${ }^{6}$ e estudiosos das ciências sociais e do direito. As análises não se restringem às condições sociais dos trabalhadores da Amazônia Legal, mas ampliam-se para contribuir com os estudos sobre o trabalho no mundo contemporâneo e ocupam um lugar central nos debates atuais. ${ }^{7}$ A gravidade social, política e econômica que o tema levanta, sobretudo o problema do "trabalho escravo" - em suas várias vertentes -, tem repercutido na Organização Internacional do Trabalho (OIT), e demarca mais um espaço de mobilização e de denúncias que reivindicam o direito à cidadania a todos os trabalhadores e a observância aos direitos humanos. A utilização de formas de trabalho compulsório não só demonstra enorme persistência, mas, o que ainda é mais grave, aparece crescendo no mundo hoje. Ao mesmo tempo em que as relações de trabalho se modificaram profundamente com as revoluções tecnológicas, formas arcaicas de relações de

6 Há que se destacar as pesquisas desenvolvidas pelos historiadores do Programa de Pós-Graduação em História da Universidade Federal de Mato Grosso, que enfocam a questão do trabalho em Mato Grosso, no século XX (com alguns textos citados neste artigo); assim como os do Programa de Pós-Graduação em História da Universidade Federal de Pernambuco que, com o Arquivo do TRT, desenvolvem várias pesquisas nesse campo temático. Ver Acioli e Assis (2011) e Montenegro, Guimarães Neto e Acioli (2011). Abreu e Lima (2005) e Dabat (2007) se constituem uma referência, na área de história, para a análise do trabalho, no meio rural, em Pernambuco, no século XX.

7 Consultar, especialmente, Conflitos no campo Brasil 2009 (Comissão Pastoral da Terra, 2010) e anos anteriores. Ver Almeida (2010), Figueira (2004), Cerqueira et al. (2008), Esterci (1994), Gomes (2008), Joanoni Neto e Castravechi (2009), Le Breton (2002), Plassat (2006, 2010), Porto-Gonçalves (2006a, 2006b), Porto-Gonçalves e Alentejano (2010), Prado (2002), Sakamoto (2004, 2005a, 2005b) e Vieira e Esterci (2004). 
exploração continuam a sobreviver e a se reproduzir em espaços que estão em constante atualização dos meios de produção com alta tecnologia.

Ao desenvolver neste artigo uma análise acerca da atuação da líder sindical Aparecida Barbosa da Silva, o meu interesse foi aproximar-me da problemática social do trabalho por vários ângulos, em particular aquele que focaliza e acompanha a sua trajetória política de defesa dos trabalhadores submetidos a práticas de trabalho que ferem os seus direitos, particularmente, degradante e escravo. Em outros termos, mesmo reconhecendo a grande importância dos estudos que enfocam as questões relacionadas à grande exploração dos trabalhadores, e a diversas formas de trabalho compulsório, trata-se, antes de tudo, de perceber as especificidades e os contextos históricos, pesando suas variáveis sociais, políticas e culturais. Sobretudo, somando-se a isso, valorizar os detalhes, os contornos mais sutis da trajetória de uma mulher que teve sua formação escolar no meio rural (pelo menos até sua chegada ao lugar de representante dos trabalhadores rurais), com todas as dificuldades com que a estrutura educacional se apresentava para ela e sua família. Tais condições e formação não a impediram de operar de maneira competente com as regras do direito trabalhista, para agir com eficácia e reivindicar a presença do MPT, dos grupos móveis de fiscalização do trabalho, da Polícia Federal a fim de acionar grandes e médios proprietários, na defesa dos direitos dos trabalhadores. São situações que se apresentam no âmbito da luta, bastante pontuais, e que merecem atenção para o uso estratégico, legal, da denúncia do trabalho escravo, ou seja, da apropriação dessa categoria na prática da denúncia, por exemplo, mas não só, pois existem outras frentes nas quais a presidenta do sindicato também se engaja. Afora isso, não se trata de escrever ou examinar mais um relato oral de uma personagem que tem uma história de luta no âmbito de um sindicato de trabalhadores rurais, em confronto direto com os proprietários de terra, particularmente os empresários do agronegócio. Sua narrativa configura-se também como ponto de partida para uma reflexão mais ampla, que ultrapassa em larga medida a sua pessoa. A memória histórica se torna emblemática para essas investigações, que buscam impulsionar os estudos da temática social do trabalho e, hoje, se ampliam com as reflexões sobre os usos políticos da memória. ${ }^{8}$

8 Sobre a problemática que envolve a discussão sobre os usos políticos da memória, torna-se importante consultar o texto de Heymann (2007), assim como as análises de Beatriz Sarlo (2007), privilegiando o debate acerca do tempo passado, experiência e crítica do testemunho. 
Ademais, a narrativa oral da representante dos trabalhadores rurais abre outras perspectivas de análise, por não se limitar a apresentar denúncias contra os direitos dos trabalhadores pobres, sem terra, mas, em especial, porque também revela a importância do relato oral como uma prática discursiva que interfere, modifica e atua na configuração da luta; denomina, conceitua e pratica uma linguagem situacional que opera na caracterização do quadro ilegal do não cumprimento dos direitos trabalhistas, exploração e trabalho degradante, que gera a possibilidade da denúncia do trabalho escravo contemporâneo. Atua, enfim, com uma linguagem que emprega palavras cruciais na ordem dos significados, em situações avaliadas como necessárias para assegurar direitos. Os trabalhadores, numa perspectiva afirmativa, são construídos, criticamente em sua narrativa, na sua condição de agentes sociais, e não como oprimidos e vitimizados. Enfatizar esse aspecto, embora se reconheça a violência social e a desigualdade de forças que se apresentam no palco das disputas, é qualificar positivamente os trabalhadores com seu poder de ação, criando táticas e brechas, negociando e disputando recursos materiais e simbólicos (Guimarães Neto, 2009).

Para os propósitos deste artigo, dividirei o texto em duas partes, que guardam entre si uma relação indissociável. Na primeira, de forma mais geral, exponho a maneira pela qual fui entrando em contato com as questões políticas e sociais que configuram histórias e experiências culturais no espaço denominado "região do Araguaia", em Mato Grosso, com forte influência da prelazia de São Félix do Araguaia. A indagação que aparece com maior insistência, relacionada à problemática deste texto, é: qual a dimensão política que toma o Araguaia nas representações daqueles que o habitam? Pode-se sintetizar a resposta com uma expressão usual entre aqueles que lá vivem e participam dos movimentos sociais pelos direitos humanos e do trabalho: "combate dos pequenos contra os grandes". Para simplificar os termos, "os pequenos" são formados por posseiros, arrendatários, parceleiros, trabalhadores assalariados, peões, homens e mulheres designados também como "trabalhadores escravos"; e "os grandes", fazendeiros e empresas do agronegócio, em especial. Nas últimas décadas, os grupos sociais destituídos de meios de produção e capital, que lá se estabeleceram, experimentaram acelerados processos de desterritorialização social. Contudo, esses processos se deram, muitas vezes, associados às estratégias de ocupaçóes de terra pelos caminhos da luta armada e práticas de sobrevivência que exigiram a criação de planos de assentamentos agrários, por parte dos governos, mobilizando o Incra (Barrozo, 
2009; Ferreira; Fernández; Silva, 1999). Nesses espaços rurais - em tempos bastante reduzidos, muitos deles se tornaram urbanos -, verifica-se o enorme peso da ocupação de áreas que não estava prevista na ordem tida como legal, ou compreendida nos planos de ocupação das terras devolutas do Estado. Os segmentos sociais, posseiros e trabalhadores sem terra, que para ali se deslocaram, desafiavam as regras hegemônicas do capital e das instituições federais e estaduais, e, ao mesmo tempo, geravam novas representações de poder no campo de luta dos trabalhadores. Poder-se-ia afirmar que a liderança de Aparecida Barbosa da Silva emerge nesse contexto.

$\mathrm{Na}$ segunda parte deste texto, procuro analisar o surgimento da liderança da presidenta no seio do Sindicato dos Trabalhadores Rurais segundo sua própria leitura e concepção. Em seguida, destaco alguns modos pelos quais a arte da palavra na narrativa oral aparece retraçando, por vias que contrariam certas visões dominantes na historiografia, as várias facetas que assume o conceito de trabalho degradante e análogo a de escravo, nomeações que hoje constituem mais e mais a designação de trabalho escravo sem aspas. A atualização do conceito se dá em novas bases históricas, e, mais do que repetir anacronismos, anuncia novas táticas no cenário político, como já foi assinalado por Gomes (2008).

Tomo como referências vários estudos que analisam a questão política da terra e a condição dos trabalhadores pobres - nas mais diversas situações sociais -, em Mato Grosso, numa perspectiva mais ampla, que abrange a Amazônia Legal; materiais de pesquisa relacionados a uma reflexão acerca dos desafios que a questão do trabalho assalariado, não assalariado, temporário, informal, apresenta. ${ }^{9}$ Desafios que não apenas questionam o status quo, mas que trazem a força da disrupção na ordem das palavras.

\section{Tempos de experiências e aprendizagens}

O interesse pela perigosa, atuante e solidária vida de Aparecida Barbosa da Silva tem uma história, que antecede nosso encontro, tece-se com diversos fios

9 As referências para um estudo mais específico acerca da questão da "ocupação da terra", práticas culturais e exploração de trabalhadores, relacionadas ao norte de Mato Grosso, entre vários trabalhos importantes, encontram-se em Barrozo (2009), Barrozo et al. (2009), Ferreira, Fernández e Silva (1999), Guimarães Neto (2002, 2006, 2009), Lima (2002), Joanoni Neto e Castravechi (2009), Oliveira (1997), Sant'Ana (2009), Soares (2004) e Souza (2009). 
que se entrelaçam entre si e apresentam, em relevo, várias outras histórias. $\mathrm{O}$ ponto marcante, ou se escolho um começo, teve início quando fui convidada a assessorar os cursos de graduação em História, pela Universidade Estadual de Mato Grosso (Unemat) na cidade de Luciara e, depois, de Confresa. Esses cursos faziam parte de um amplo projeto de ensino denominado Parceladas, realizados nos períodos de férias (meses de julho, janeiro e fevereiro), a fim de atender professores e professoras da rede de ensino fundamental e médio. Tiveram um papel muito importante na formação desses professores; na área de história, foram os primeiros a ser realizados na "região do Araguaia”, em sua dimensão cultural.

O símbolo Araguaia se associa à representação de um território de luta política, que registra um dos mais significativos conflitos por terra no Brasil, entre empresas multinacionais, grandes e médios fazendeiros e grupos sociais desprovidos da posse legal da terra, posseiros, que naquela área já se haviam estabelecido desde os finais do século XIX; além disso, foi palco de grandes ameaças e violências armadas durante o regime civil-militar. Para além da truculência desse período, os conflitos por terra e a exploração de trabalhadores rurais avançaram pelas décadas de 1980, 1990, adentrando o século XXI, destacando-se confrontos armados, inúmeros assassinatos de trabalhadores, crescimento do uso do trabalho análogo a de escravo e diversos atos reveladores do não cumprimento de direitos trabalhistas e do mais completo abuso aos direitos humanos.

Todavia, este Araguaia é também conhecido como a terra da resistência da prelazia de São Félix do Araguaia, com o bispo Pedro Casaldáliga, força exemplar da luta pelos direitos humanos, símbolo do combate à ditadura militar e fonte da maior inspiração da nossa personagem principal, Aparecida Barbosa da Silva. Em especial, D. Pedro Casaldáliga foi um dos primeiros a desencadear as denúncias de trabalho escravo na Amazônia, nos anos iniciais da década de 1970, período mais crítico da ditadura civil-militar. Como é de conhecimento público, D. Pedro Casaldáliga ainda está vivo por um golpe de sorte, pois sofreu várias tentativas de assassinato.

A prelazia de São Félix tem ligações importantes com o projeto de ensino das Parceladas no Araguaia, em diálogo constante com sua linha de atuação política. O bispo Pedro Casaldáliga rezou a missa de formatura da primeira turma de história do projeto das Parceladas. Ao concluir seu sermão, D. Pedro Casaldáliga, que conhecia a história das famílias de trabalhadores que tinham agora seus filhos e suas filhas se formando, era capaz de apontar 
para muitos e contar um pedaço de sua história, que se misturava à história dos conflitos e confrontos havidos no Araguaia. Uma memória política ali se estendia e escrevia um texto vivo.

Nesse sentido, posso afirmar que os cursos de história no Araguaia são um marco em minha vida. Foram muitas e desafiantes aprendizagens. Pude conhecer de perto situações bastante difíceis de nossos estudantes-professores, experiências que reúnem acontecimentos que, somados, escrevem uma crônica social e política do Brasil, de norte a sul. Ali se entrecruzaram tempos diversos, em dimensões superpostas, que desfiam histórias das mais diferentes personagens; aquelas que protagonizaram acontecimentos reveladores de violências inomináveis, assim como a história dos deslocamentos familiares e individuais, longas travessias pelo território nacional, a que foram submetidos os segmentos de trabalhadores sem terra e pequenos proprietários, pressionados a abandonarem suas terras. As difíceis condições de produção e reprodução dos pequenos agricultores, particularmente da região Sul, os tornavam alvos prediletos dos apelos das propagandas dos empresários que prometiam o Eldorado em terras amazônicas, especialmente dos projetos ditos de colonização; e, também, trabalhadores sem terra do Nordeste acreditaram nas propagandas das vantajosas ofertas de trabalho em fazendas agropecuárias (onde, muitas delas, de fato, praticavam o trabalho análogo a de escravo). Os relatos que nos cursos eram expostos contam da filha, do filho, do pai, da mãe, do irmão, da irmã que se mudaram do Sul para o Norte, famílias inteiras ou em pedaços. Em outros tempos, da mesma forma, também haviam se dirigido do Norte ou Nordeste para o Sul ou Sudeste. É uma história social das migrações, ou melhor, dos deslocamentos de grupos sociais no Brasil, que não têm como se estabelecer na sua propriedade ou posse de terra, nem como garantir a sobrevivência do grupo familiar. E, ainda, oferece um quadro que contextualiza as lutas políticas pela terra nessa parte do país.

Desse modo, aí se ouvem as histórias de jovens que tinham perdido os pais quando estes enfrentaram pistoleiros das fazendas que apareciam para atemorizar, cercar ou tomar a sua terra (Souza, 2002); que presenciaram a catástrofe de ver suas casas/ranchos serem atravessados ao meio por uma cerca de arame farpado, pressionando o retalhamento de sua própria terra, ou o que chamamos de processo de expropriação (Esterci, 1987; Souza, 2009). Relatos diversos, testemunhos e declarações daqueles que vivenciaram uma verdadeira guerra pela posse da terra, como a da filha, professora Isabel, que conta a história do pai, que foi torturado pelos pistoleiros da fazenda Bordon, 
vindo a falecer, depois, em razão dos espancamentos. Seu pai havia negadose a assinar um documento que autorizava a ligação de uma estrada entre a comunidade e a Agropecuária Bordon (Silva, 2006). D. Pedro Casaldáliga orientava as comunidades de posseiros a não assinarem nada com as agropecuárias, ensinando-os a abrirem poços d'água, a construírem e realizarem beneficiamentos nas suas áreas de ocupação, estabelecendo o direito à terra, praticando formas de resistência. Mas agora, durante o curso de História das Parceladas, podia-se ver o outro lado dessa luta: professores que se sentavam nos bancos de salas mal-arrumadas (um calor infernal, muita poeira, crianças pelos corredores à espera das mães para serem amamentadas...) a contar e ouvir essas histórias, retirando-as do silêncio, talvez até do esquecimento, e, dessa maneira, contribuindo para construir outra historiografia do Brasil. Todo esse enorme, desafiante e difícil caminhar resultava também na obtenção de um diploma universitário. Vitória indescritível!

Muitos daqueles professores que ali se encontravam trabalhavam em condições bastante difíceis, chegando a viajar 600 quilômetros em estradas não pavimentadas, com muita poeira, buracos, pontes de madeira semidestruídas, muita lama, áreas intransitáveis, para concluírem sua formação intelectual. Diante de homens e mulheres marcados por tantas histórias, para mim, muitas, até então desconhecidas, o que tínhamos a ensinar? Tenho certeza que mais aprendi, uma aprendizagem inigualável, para toda a minha vida. Aprendi, também, que meu vocabulário era inapropriado para me expressar e fazer-me entender por aquelas pessoas. Não apenas por uma questão de vocabulário; havia uma sintaxe, uma criação, uma relação entre as palavras que se combinam, se digladiam, promovem aproximações e disjunções - lembrando as reflexões de Wittgenstein (1979), como Verena Alberti (2008) também encaminha em sua leitura desse autor, relacionando com a história oral os “jogos de linguagem”, as palavras e o seu uso na linguagem - que, ali no Araguaia, eram totalmente novas para mim. Não restava outra saída, tinha que aprender, ou não haveria comunicação entre nós, e eu perderia aquela grande experiência. Palavras e sintaxes que surgiam criativamente, num "jogo de linguagem”, como num batismo de fogo a me desafiar uma nova iniciação com as palavras, com a gramática da vida. Ou melhor, como Manoel de Barros (1990, p. 298) apreende o movimento constante da reinvenção das palavras:

Um sub-texto se aloja. Instala-se uma agramaticalidade quase insana, que empoema o sentido das palavras. Aflora uma linguagem de defloramentos, 
um inauguramento de falas. Coisa tão velha como andar a pé. Estes vareios do dizer.

E as palavras fluíam nas narrativas das mulheres e dos homens que ali estavam a traçar verdadeiras cartografias e a se fazer também aprendizes da história de uma longa e difícil experiência das suas vidas, do Brasil... Palavras que ficaram inscritas nos papéis de suas monografias.

Com o curso de História (havia também os cursos de Letras, Matemática, Geografia, Biologia) concluído, aqueles professores e professoras, naquele momento estudantes, puderam dar continuidade às suas carreiras no magistério. Também tiveram melhores condições de não só ocupar a terra, furar seus poços d'água ou trabalhar nas pequenas cidades e vilas que se multiplicaram rapidamente, mas experimentaram/provaram a gramática da terra, para usar ainda aqui a inspiração do livro do poeta Manoel de Barros, e imprimiram sobre esse barro, sobre aquela matéria, a sua técnica e as suas lições.

\section{Experiências como fonte de pesquisa}

Outro registro riquíssimo dessa experiência projeto Parceladas que ainda quero destacar se refere ao trabalho de final do curso. Para poderem se formar, os estudantes tiveram que escrever suas monografias. A base documental da maioria das pesquisas contemplou a ocupação recente da parte norte do estado de Mato Grosso. Produziram uma verdadeira cartografia dos itinerários percorridos no processo de ocupação, em que suas famílias, parentes e conhecidos eram os principais personagens.

Expuseram histórias de "retirantes", de "colonos", de "migrantes". Estes últimos termos foram ressignificados por eles, como o de migrante, que as ciências sociais tomaram de empréstimo da biologia. Agora, eram homens e mulheres que tinham nome e história, rompendo o círculo vicioso do anonimato. Por isso, era tão importante apresentarem suas narrativas escritas, que partiam dos relatos orais de memórias colhidas por meio de entrevistas ou, muitas vezes, resultantes dos próprios registros das histórias ouvidas, repetidas vezes, nas rodas familiares e de amigos. Procurávamos ajudá-los a trabalhar e a produzir os textos escritos, segundo regras estabelecidas no campo da história. A noção de documento aí era amplamente debatida, mas dentro dos limites possíveis daquelas experiências. Ensinávamos/aprendíamos que a 
matéria da vida - memória social - também pode ser tratada de modo a nos fornecer indícios das experiências sociais, em tempos e espaços instituídos como históricos; orientávamos também os estudantes a pesquisarem nos arquivos da prelazia de São Félix do Araguaia, ${ }^{10}$ nas câmaras municipais e cartórios, jornais, ofícios, processos trabalhistas, inventários; discutíamos sobre a importância de cruzar a fonte escrita com as fontes orais e fotográficas e vice-versa, tão necessárias para a história do tempo presente. É o que podemos apontar como uma experiência de aprendizagem, tão ampla e significativa. Alguns deles seguiram a carreira acadêmica, fizeram mestrados e se habilitam agora a seguir o seu doutorado. Creio que em minha vida acadêmica essa é a experiência que mais me gratifica e me emociona por todo o seu significado político, cultural e social, relacionando história, educação e política, memória e história, arte e vida.

É com essa prática, carregada de tantos significados, marcas e aprendizagens, que o projeto Parceladas/Unemat deu prosseguimento à segunda turma de História, já na cidade de Confresa. Ali encontrei Aparecida Barbosa da Silva. As pesquisas, nessa segunda turma, vieram marcadas por outras temáticas e a questão que mais me chamava atenção era a da exploração dos trabalhadores circunscritos às grandes fazendas e agroindústrias, destacando-se o estudo do trabalho análogo a de escravo. A violência da ocupação e das condições de trabalho naquela vasta área encontrava-se viva na memória da maioria dos alunos daquela turma, e era a todo o momento atualizada por novos acontecimentos. O debate em sala de aula sobre esses assuntos fez a turma citar Aparecida Barbosa da Silva, comentar sobre essa mulher que paralisava indústrias e denunciava fazendeiros que não cumpriam com suas obrigações trabalhistas.

Também avaliávamos essa dolorosa e longa história de mais de três décadas de ocupação, cujos resultados - florescimento a todo vapor do agronegócio - discutíamos, relacionando o poder econômico de implantação das empresas ligadas à produção de grãos à formação das grandes lavouras e indústrias biocombustíveis e, especialmente, investigando como era tratada/

10 O Arquivo da Prelazia de São Félix guarda documentos preciosos acerca da luta pela terra no Araguaia e da importância de Pedro Casaldáliga e de outros padres que com ele se envolveram diretamente na defesa dos direitos dos povoados e comunidades e de pessoas que sofriam a arbitrariedade de poderosos grupos de proprietários armados; o Jornal Alvorada, da prelazia, continua a prestar importantes informações sobre a luta pela defesa dos direitos humanos e a atualizar uma memória histórica da violência (ver http://www. prelaziasaofelixdoaraguaia.org.br). 
utilizada a mão de obra, as formas de coerção ao trabalho. Do desmatamento à grande lavoura, voltada para o agronegócio e à exportação, primordialmente, o cenário ali não se apresentava em um quadro evolutivo, era marcado pela simultaneidade: desmatava-se, plantava-se; plantava-se e desmatava-se; do corte da cana ao processo industrial da produção de álcool; do trabalho legal ao trabalho ilegal. As condições precárias de alimentação, moradia e saúde dos trabalhadores feriam os direitos humanos e trabalhistas e indicavam o que era chamado de trabalho degradante para caracterizar a situação de "análogo a de escravo".

Por outro lado, também já era possível sentir os efeitos de um sistema político que conta com uma Justiça do Trabalho, Ministério Público, Ministério do Trabalho, Ministério do Trabalho e Emprego e Polícia Federal comprometidos com o estado de direito e a democracia (embora continue havendo impunidades, corrupção e práticas ilegais, com trabalhadores sendo libertados todos os dias). Mas são outras condições políticas no país e nelas é que se situa a presença de Aparecida, embora o assassinato de Dorothy Mae Stang esteja, como um espectro, a rondar a vida de Aparecida Barbosa da Silva, que também já recebeu várias ameaças de morte. Contudo, há um diferencial histórico, não há como negar. A configuração de poder apresenta outros atores sociais no intricado jogo de disputa no campo, considerando o tempo de chegada àquela área das primeiras famílias e trabalhadores sem terra, que, praticamente, só contavam com a voz e o apoio do bispo de São Félix do Araguaia, D. Pedro Casaldáliga, quando foi criada a CPT. Ela - por meio de suas denúncias, fundamentadas em lei - conseguiu que a Polícia Federal e o Ministério Público autuassem e fechassem por diversas vezes, por exemplo, a principal agroindústria ali localizada, a destilaria Gameleira, hoje renomeada Araguaia (depois de ser registrada várias vezes na lista suja de empresas que cometem ilegalidades, como o uso de trabalho escravo). E não só denunciou a Gameleira/Araguaia, muitos outros fazendeiros ali também foram fiscalizados, autuados e exigidos que cumprissem suas obrigações legais na relação com os trabalhadores por eles empregados.

É no turbilhão dessas histórias que ganha significado político o testemunho do relato de Aparecida Barbosa da Silva, lembrando Walter Benjamin (1985) quando diz que os mortos estão a exigir dos vivos a palavra que possa libertá-los; linguagem política que entende o passado como presença que não passa, e que pressiona/coage a estabelecer os capítulos da história acerca dos temas que escrevemos para o futuro. 


\section{Tempo das entre-vistas}

Fiz várias entrevistas com Aparecida Barbosa da Silva, que somam aproximadamente seis horas gravadas, em final de janeiro, parte do mês de fevereiro e julho de 2006. É preciso contextualizá-las em um breve relato. Trazem as marcas das operações da linguagem, em que a relação entre as palavras é provocada pelos diálogos que se estabelecem e também pelas interações muito particulares que se criaram entre nós, diante dos caminhos que trilhamos. Houve um diálogo ativo, criativo e nada neutro; dialogamos também com os olhares, sorrisos, interrogações e silêncios; inscrições diversas no mundo dos signos. Em nossos encontros nos olhávamos e escutávamos atentamente, indagando uma e outra. Portelli (2010) toma, em seu texto, essa questão da entrevista como objeto de reflexão. Assinala a relação entre história e memória na experiência da pesquisa de campo, por meio das entrevistas que realiza, e analisa o ato da entre-vista como resultado do trabalho comum, do diálogo estabelecido entre o entrevistador e o entrevistado ou entrevistados. Assim sendo, para ele há uma troca de olhares, a partir de percepções distintas que se comunicam e produzem "entre-vistas". É nessa relação que Aparecida e eu procurávamos compreender-nos, conhecedoras de antemão de nossas diferenças sociais, que nos inscrevem na diversidade cultural. Saber reconhecer as diferenças sociais e culturais é um primeiro passo para qualquer entrevista que busca romper com os lugares dispostos em uma concepção positivista, ou seja, com os tradicionais papéis de sujeito e objeto, observador e observado (Portelli, 2010).

As entrevistas realizadas contêm os vestígios das condições precárias com as quais nos defrontávamos. No espaço onde tínhamos que realizar nossa atividade havia muito barulho, gente entrando e saindo da sala da escola (uma escola pública, onde funcionavam os cursos das Parceladas, pela Unemat em Confresa), ou um quarto abafado do hotel, onde me encontrava hospedada - praticamente o único em condições viáveis - e, para complicar, o celular dela não poderia ficar desligado. O seu tempo não se encontrava inteiramente disponível para mim, isso era impossível... Havia operações, muitas vezes, urgentes em que ela teria que comparecer ou dar algum parecer por telefone. Aparecida é uma mulher que não para nunca! E, ainda, tínhamos que driblar pessoas que não poderiam ouvir o seu relato (o dono do hotel, certos estudantes...). No entanto, ao mesmo tempo, as condições adversas também 
geravam e fortaleciam a nossa cumplicidade e o desejo de cumprir o nosso intento. Aos poucos, ela trazia mais informações, mais histórias, acrescentava fotos; além disso, outros acontecimentos ocorridos em Confresa, cidades e comunidades próximas vinham somar-se à situação das entrevistas. ${ }^{11} \mathrm{E}$, em outro momento, ela me chamou até a sede do Sindicato dos Trabalhadores Rurais para entrevistar um casal que havia acabado de sair de uma fazenda, de uma situação que se configurava como de trabalho escravo. Tornava-se cada vez mais claro: fazíamos um esforço grande e corajoso para que os desafios fossem muito bem enfrentados.

Entretanto, o maior deles foi quando apareceram quatro pistoleiros armados na pequena sorveteria de seu filho, no momento em que conversávamos para marcar a última entrevista, que se daria no dia seguinte. Já estava tarde, eram aproximadamente $21 \mathrm{~h} 15$, e somente ela e eu nos encontrávamos no local. Eles pediram sorvete e lá ficaram por um bom tempo. Ela me olhou e fez sinal, alertando-me sobre o tipo de pessoas que eram. Ficamos mais ou menos calmas e esperamos. Creio que minha presença ali, provisoriamente, inibiu qualquer coisa que poderiam fazer, porque depois de um tempo eles foram embora (por volta das 22h). Quando seu filho retornou, disse que estava tudo bem. Pude, então, ir para o hotel, que era bastante próximo a esse local. Mas, para surpresa deles, logo após minha saída, os pistoleiros voltaram e os acuaram no fundo da sala da sorveteria, quando, nesse mesmo instante, seis pessoas chegaram para pedir sorvete. Os suspeitos, um pouco atordoados, se retiraram e, então, Aparecida e o filho chamaram imediatamente a polícia. Os pistoleiros evaporaram. E ninguém mais os viu ou ficou sabendo deles.

11 Por exemplo, o julgamento de Luiz Carlos Machado, o Luiz Bang, na cidade de Porto Alegre do Norte, em 31 de julho de 2006. Essa cidade se localiza, aproximadamente, a $30 \mathrm{~km}$ de Confresa. Luiz Bang é conhecido pelos seus atos de grilagem de terras, aliciamento e tráfico de trabalhadores para as fazendas de Mato Grosso e Pará, além da prática de trabalho escravo; ele, segundo o que é de conhecimento público, iniciou sua vida ali como pistoleiro, chegando a ocupar o $5^{\circ}$ lugar da lista dos pistoleiros mais procurados do Brasil. O julgamento foi um verdadeiro ato político, que contou com a presença de Pedro Casaldáliga, porque Luiz Bang era julgado pelo crime de tentativa de duplo assassinato do ex-prefeito Rodolfo Alexandre Inácio, o Cascão, e do segurança Avelino Pereira Coelho, ocorrida em novembro de 1988. Cascão seguia, na época, a linha política da prelazia de São Félix do Araguaia. Estavam presentes, também, representantes de entidades ligadas aos movimentos sociais, representantes da CPT, jornalistas e Aparecida Barbosa da Silva, além de nós, professores e professoras das Parceladas, e estudantes do curso de História. Durante todo o julgamento o clima foi de muita insegurança e medo. Diziam que Luiz Bang, em caso de condenação, acionaria um famoso pistoleiro para assassinar o juiz e o promotor. Luiz Bang havia também ameaçado membros do júri. Foi absolvido por 4 a 3 . O promotor iria recorrer contra a sentença. 
Ao trabalhar com a prática metodológica da história oral, as entrevistas aparecem para tornar mais complexa a cena viva e o ato narrativo, no sentido de "complicar", abraçando o significado latino da palavra: "dobrar enrolando". ${ }^{12}$ São nas diversas dobras que a narrativa transforma acontecimentos, experiências e práticas em histórias (Deleuze, 1987).

\section{Tempo, linguagem e história: Aparecida Barbosa da Silva}

As entrevistas com Aparecida realizaram-se sob pressóes de diversos tipos, elas próprias transformando-se em outro acontecimento. Predominava uma linguagem menos formal, como que aderida à camada fina da nossa pele, que emprestava elasticidade aos nossos múltiplos gestos, atentos ao inesperado. Gestos que seguiam as narrativas que fluíam pelo rio de suas memórias, com os portos assinalados, nos quais ancorávamos com o apoio de seu ponto de vista político acerca da luta pela terra. Aparecida direciona a sua narrativa, escolhe o quer dizer, como a desenhar com palavras todo aquele cenário de lutas, enfrentamentos, conflitos, medos e negociações. Interessa-me não apenas o que ela diz, mas como narra, a sua produção discursiva. Nem por isso havia inflexibilidade na travessia que empreendíamos, tomávamos, algumas vezes, caminhos desconhecidos. A entrevista oral se move de acordo com a experiência que vamos partilhando, com as práticas e saberes de uma e de outra. Minhas perguntas, algumas vezes, levavam-na a perscrutar problemas sob ângulos ainda não refletidos e a explorar outros mundos, assim como eu, diante de suas respostas. Para ela, além disso, o relembrar significou descobrir-se ou redescobrir-se, dizendo, sentindo e pensando situações/emoções, casos, acontecimentos, algumas vezes, não inteiramente sabidos. Não se trata de realizar uma leitura da sua subjetividade em oposição a uma objetividade, mas de estar atenta "[...] à sua formulação como discurso, aos seus encadeamentos lógicos e semânticos, à sua função de produtora de sentido", como assinala Benito Schmidt (2009, p. 2). Aparecida traz em seu relato outros atores sociais, fala de um lugar compartilhado com múltiplas vozes que vivenciaram

12 Segundo o dicionário Houaiss: “enrolar, enroscar, dobrar enrolando”. 
experiências comuns. O relato oral encontra-se inserido na rede das relações sociais e não se fecha ou contém em si mesmo um fim pré-ajustado, pois, de outro modo, anularia a riqueza da reconstrução mnemônica e discursiva que opera a produção de novos significados. ${ }^{13} \mathrm{E}$, a esta altura, é importante enfatizar, ainda, que o relato oral também não pode ser analisado sem contar com as vicissitudes do tempo histórico, como assinala Antônio Montenegro (2010, p. 43):

Percorrer a trilha do relato construído é visitar um labirinto de muitas voltas, de muitas dobras, que ao se desfazerem aproximam passado e presente, distanciam passado e presente, numa tensão de quem conhece o poder das palavras, de quem sabe quanto elas significam: um perigoso campo minado.

Em uma parte das entrevistas, Aparecida diz: “[...] para falar do hoje, eu falo do ontem". Nesse jogo de temporalidades, em que o ato das entrevistas orais conduz e provoca os diálogos, revela-se a complexidade dos testemunhos, experiências e práticas, que, passo a passo, constituem-se matéria-prima da história. Segundo Maria de Lourdes Janotti (2010), os "testemunhos espontâneos ou provocados possuem implicações teóricas" que geram diversos aspectos a serem considerados:

Envolvem repensar as relações entre realidade e representação, memória e história, veracidade e imaginação, versão e factualidade, unidade conceitual do testemunho e pluralidade de fontes, acima de tudo, o caráter intrinsecamente político do testemunho e seu problema.

Ao privilegiar para análise o relato oral de Aparecida Barbosa da Silva, nos limites do presente texto, procuro considerar, em especial, "o caráter intrinsecamente político do testemunho", como orienta Janotti, e o problema que se propõe a construir, ou seja, a criação de um sindicalismo comprometido com a defesa dos direitos trabalhistas e humanos, na linha política da prelazia de São Félix do Araguaia e da Comissão Pastoral da Terra, com

13 Consultar o excelente texto de Maria de Lourdes Janotti publicado neste dossiê acerca dos problemas teóricos e metodológicos que enfrentam os historiadores ao lidarem com o tecido complexo das rememorações, em textos, testemunhos escritos ou orais. 
potencial para enfrentar a desigualdade social entre grandes proprietários e pequenos produtores do campo, politizando completamente a questão agrária no Brasil. O problema do trabalho escravo no tempo histórico presente é a pedra angular desse relato oral e o testemunho que encerra não fica circunscrito à denúncia; ele é prática política, capaz de fechar grandes empresas agropecuárias e/ou industriais, nacionais e multinacionais; de acionar a justiça e o Estado para libertar trabalhadores em situação de trabalho escravo, entre tantas outras ações efetivas.

\section{Primeiras palavras}

Em cada parte do diálogo, Aparecida Barbosa da Silva monta devagar um quebra-cabeça, em que peças - momentos importantes de sua vida - aparecem para reforçar a sua trajetória direcionada à "luta pela terra". Desde os tempos de menina/moça, ajudava o pai, carpindo na roça; não gostava de ler revistas em quadrinhos, mas livros e depois os livros de D. Pedro Casaldáliga, que lhe ofereciam uma visão de mundo ou mesmo uma percepção do universo da desigualdade social e defesa dos direitos humanos. Foi preciso passar pela aprendizagem da escola (os primeiros anos no ensino fundamental); trabalhou como professora em uma escola da comunidade onde morava; e resoluta foi a sua prática em uma área de posse, correndo risco de vida, juntamente com sua família, aprendendo a tomar iniciativas de resistência e a reivindicar seus direitos junto ao Incra. A liderança marcante que, depois, se formou no âmbito do Sindicato dos Trabalhadores Rurais de Confresa é resultado de escolhas difíceis, mas decisivas. A líder sindical se tornará conhecida no cenário político de Mato Grosso e mesmo nacional; também será temida por algumas das empresas do agronegócio, dentro e fora desse estado; amiga de D. Pedro Casaldáliga, com quem se aconselha, e em constantes articulações e parcerias com a CPT regional e nacional, apresentar-se-á de maneira despretensiosa, com uma "dura" simplicidade que encanta e enfurece (proprietários de terra), em defesa dos trabalhadores.

Iniciamos as entrevistas quando Aparecida pôde organizar o seu tempo para conversar e relatar suas histórias que se relacionam ou dialogam com as histórias de homens e mulheres de diversas partes do Brasil. Exponho a 
seguir alguns trechos dessa entrevista com minhas análises. ${ }^{14}$ Aparecida Barbosa da Silva, aos 53 anos de idade, apresenta-se:

Não sei o que tenho... Não consigo sentir medo. Mas todo mundo morre. Minha família vivia em pânico, porque eu sou muito perseguida, com esse trabalho meu. Agora, em agosto tem minha irmã que trabalhava aí na pastoral da criança, um trabalho bem pacífico, sem risco... Aí morreu de acidente, na roça. Minha família viu que quando tem de morrer acontece, trabalhando em qualquer coisa. Minha irmã que nunca mexeu com essas lutas perigosas que eu mexo, com 59 anos, mãe de nove filhos. Não esperava isso, nunca foi perseguida, e morreu por acidente. Então morrer, qualquer um morre. Eu não acho que, por causa de perigo de morte, eu vou deixar minha luta que eu gosto, não! Vou lutar, se eu tiver 15 dias de vida, eu vou lutar esses 15 dias, eu não desisto, eu acho que vale a pena, acho que minha vida é dar a luta por isso. ${ }^{15}$

O episódio da morte da irmã e sua "vida em perigo" são associados para, ao opor dois acontecimentos dramáticos - a morte que ocorreu, o falecimento da irmã deixando nove filhos, e a morte que pode ocorrer a todo o instante, diante das várias ameaças - poder marcá-los como uma tragicidade menor, diante do que pode ocorrer com a imobilidade e o medo que aprisiona a vida. O trecho da entrevista é também o relato de uma aprendizagem: exercita a arte de enfrentar o medo que cerca aquela opção de vida de lutar pela defesa dos direitos trabalhistas e da justiça. Tal postura encontra ressonância no discurso da CPT e dá sentido à sua conduta, ou seja, a sua ação política não se separa da sua vida privada; esta, de agora por diante, se efetiva no espaço público, defendendo um sindicalismo autêntico, combativo, que não

14 O conjunto das entrevistas será analisado em outros textos que comporão o livro sobre a questão social do trabalho e as práticas de trabalhadores, em parceria com Angela de Castro Gomes. Para o trabalho com o material das entrevistas, observo as análises teóricas de historiadores e historiadoras que utilizam a prática metodológica da história oral, em diálogo com outras fontes documentais: Alberti (1990, 2008), Del Castillo Troncoso (2006), Delgado (2010), Duarte, Kramer e Laverdi (2009), Gomes (2004), Gomes e Pessanha (2010), Gracia (2005), Faria e Montenegro (2005), Ferreira e Amado (1996), Funes (2009, 2010), Funes et al. (2009), Harres (2009), James (2010), Janotti (2005, 2010), Luca (2005), Maia (2009), Mauad, Gomes (2006), Mauad, Knauss (2006), Montenegro (2002, 2010), Montenegro et al. (2008), Montysuma (2006), Nascimento e Monte (2009), Pedro (2010), Portelli (2010), Pozzi (2010) e Smith (2010).

15 Essa primeira parte da entrevista foi realizada em uma sala do espaço da escola onde funcionava o curso de História do Projeto Parceladas/Unemat, em Confresa, em 30/01/2006. 
recua diante dos perigos, pelos direitos dos trabalhadores. Nesse contexto, que reúne aspectos e circunstâncias que se assemelham, Airton dos Reis Pereira, da CPT do Pará, rememora os sindicalistas assassinados João Canuto (Rio Maria), Expedito Ribeiro de Souza (Rio Maria) e José Dutra da Costa, o Dezinho (Rondon do Pará), que percorreram caminhos, hoje, trilhados por Aparecida Barbosa da Silva, e faz a seguinte afirmação:

Todos eram meus colegas. Mesmo ameaçados de morte procuravam driblar o medo. Não sei onde encontravam tanta força, talvez na mística da própria luta junto aos trabalhadores. Estes sindicalistas tiveram a sua trajetória de aprendizagem no seio de um "setor" da Igreja Católica, adepto da Teologia da Libertação. Maria Joel Dias da Costa, viúva de Dezinho, depois de algum tempo, continuou a luta do marido. Foi presidente do Sindicato dos Trabalhadores Rurais de Rondon do Pará por dois mandatos e agora é coordenadora regional Sudeste (Pará) da FETAGRI. Dois policiais fazem a sua segurança diariamente. É ameaçada de morte por grandes proprietários de terras. Talvez a opção política de Aparecida seja marcada por tantos exemplos de sindicalistas e outros lutadores que dedicaram as suas vidas à luta pelos direitos dos trabalhadores e pela justiça no Brasil. Lidar com o medo e com a possibilidade da morte foi algo presente na vida desses homens. E agora dessas mulheres. ${ }^{16}$

\section{O Sindicato dos Trabalhadores Rurais: a mobilização pelos direitos dos trabalhadores}

Com voz tranquila e muito determinada, Aparecida segue afirmando sua postura combativa e começa a narrar a criação do Sindicato dos Trabalhadores Rurais de Confresa, em 1996, e os rumos que os acontecimentos foram tomando. No mandato de 2002-2004, fez parte da diretoria, como tesoureira. Constrói a sua participação no sindicato, nessa gestão, e argumenta como foi sua prática, especialmente sua habilidade para orientar os trabalhadores, e

16 Airton dos Reis Pereira é membro da CPT/Pará e também professor da Universidade Estadual do Pará. $\mathrm{O}$ trecho citado encontra-se em carta endereçada a mim, intitulada "Reflexões sobre violência, política e trabalho no campo". Ver também Pereira $(2008,2010)$. 
fazer do sindicato um espaço de reivindicações e apoio trabalhista, até passar a ocupar aí um lugar central. Ser eleita para o cargo de presidenta era uma decorrência do trabalho realizado até aquele momento; mais que isso, era uma necessidade. Acerca desse percurso de mobilização e prática, relata:

Os trabalhadores vinham todo domingo, final de semana, eles vinham. [Nas ruas da cidade] foram pondo os orelhões... E você vê, dá para identificar os grupinhos. Eu começava a conversar com quem tava lá, sou voltada pra isso, a minha preocupação era essa, com os que estavam lá. Mesmo quando eu não era presidente ainda, mas eu fazia parte da diretoria. $\mathrm{O}$ presidente não gostava disso. Ele não gostava que eu pegasse liderança. Simplesmente eu mexia com o dinheiro do sindicato, que era o meu ponto fraco, não sou acostumada com isso. Aí eu começava a mobilizar eles, e falava, olha se acontecer qualquer coisa lá eu sou a tesoureira, se o presidente não quiser atender vocês, falem comigo, meu nome é tal... Se quiserem conversar no sindicato eu posso conversar com vocês, junto com o presidente, mas se quiser encontrar em outro lugar, conversar com ele num orelhão, na rua, na esquina [...] Comecei a mobilizar eles, e começaram a acreditar no meu trabalho e denunciava. [...] teve uma negociação que eles ficaram com muita raiva do presidente, porque ele passou por cima da reivindicação deles, o presidente favoreceu a Gameleira [destilaria de álcool de cana-de-açúcar], falou que a Gameleira tava com a razão... Ao invés de reivindicar junto com os trabalhadores, ele deu razão para a Gameleira e, aí, eles ficaram com muita raiva nessa época. Por aí que eu vi a necessidade que eu tinha de me candidatar a presidente, não pela empáfia de ser presidente, mas pela necessidade da defesa dos trabalhadores. [...] A questão trabalhista aqui é uma loucura! Agora, se o sindicato, se todo mundo que vem bater na porta do sindicato, ele [o antigo presidente] dizia que não podia, porque o fazendeiro era perigoso, e [por isso] não podia... não havia condições! Aí comecei a fazer um trabalho... Como eu era tesoureira, comecei a fazer um trabalho, atendendo as questôes trabalhistas. $O$ pessoal começou a ver o meu trabalho, a importância do meu trabalho, por isso não foi por um querer meu, mas foi o próprio trabalhador que exigiu que eu me candidatasse... Que eu criasse uma chapa. Eu faço o melhor que posso, ele - o antigo presidente - era muito medroso, não por maldade, por não ser uma pessoa má, mas ele era medroso com a questão do fazendeiro. Aí vinha o pessoal da Gameleira, e ele falava o mesmo, que a Gameleira era muito bandido, que tinha muito bandido na Gameleira, que já tinha outro presidente do sindicato 
que teve que correr por causa da Gameleira, que a Gameleira perseguiu ele, o presidente anterior, que ele correu pro Pará. Depois de muito tempo, nós ficamos sabendo que ele tava no Pará, e deixado os materiais do sindicato, sem acabar, nem entregou, saiu às carreiras, sumiu que ninguém sabia dele. Saiu com a família, deixou tudo... E é aí que eu acho, que se cada vez que esse povo bate pé e levanta a poeira, a gente correr, não tem luta! Porque bater o pé, eles batem pra todo mundo, não é que a gente tem que ser ignorante, corajoso, não; mas você tem que enfrentar. Afinal pra onde vai o trabalhador se todo mundo correr!

Nesse trecho da entrevista é possível acompanhar a mudança que se produz em sua tática política, saindo rapidamente da esfera da ação individual para a vida coletiva e pública. E oferece então um histórico do seu trabalho político e de sua dimensão "pedagógica", ou seja, conversando e conquistando o trabalhador para o sindicato, mesmo que ele não tivesse, ainda, confiança na atuação dos seus dirigentes. Era preciso que os trabalhadores aprendessem que o poder da grande empresa não era imbatível e deveria ser enfrentado, com organização e conhecimento da legislação, para garantir o correto encaminhamento das questões trabalhistas. A destilaria Gameleira, hoje destilaria Araguaia, do Grupo EQM (Eduardo Queiroz Monteiro), era emblemática para esta luta. Ali se praticava uma série de irregularidades: exploração dos trabalhadores, sabidamente muitos deles em situação do que era nomeado como trabalho escravo, vindos em sua grande maioria do Nordeste do Brasil. O relato de Aparecida acerca das condições de trabalho na destilaria Gameleira é revelador das práticas de uma grande empresa, no século XXI, que, além de não respeitar as leis trabalhistas, adota práticas que ferem completamente o direito à vida. Segundo as reflexões de Airton Pereira, essas práticas

[...] coadunam, talvez muito mais do que em épocas anteriores, velhas e novas práticas de atores que violam os direitos humanos no campo. Práticas de velhos latifundiários são hoje evidenciadas e/ou ressignificadas por grandes grupos econômicos do agronegócio, na Amazônia. Grandes proprietários de terras que negociam diariamente as suas ações nas bolsas de valores no Brasil e no exterior; que utilizam da alta tecnologia na produção de grãos, etanol, gado, etc. e são defensores da competitividade e da modernidade, utilizam-se da violência e de um dos métodos mais arcaicos para aumentar 
o seu lucro, que é o trabalho escravo. Há uma simbiose entre o novo e o velho. As designações "latifundiários" e "empresários do agronegócio" são complementares, não opostas, porque ambas inscrevem-se em um mesmo espaço de referências e de significações; englobam a improdutividade, o trabalho escravo, o crime ambiental, a violência e o lucro. ${ }^{17}$

A narrativa de Aparecida flagra imagens que detalham o cotidiano na moradia, a situação da saúde e da alimentação, a jornada excessiva de trabalho, dos que ali se encontravam "bebendo água tão suja que parecia suco!":

Foi logo nos dias que eu fui eleita presidente, eu fui lá fazer uma visita. Aí fui em todos os três, tem três alojamentos [...] Eu vi que tinha gente doente, que não tinha ido aquele dia para o serviço; fui também no serviço, visitei eles cortando cana, porque quando a gente chega no serviço o fiscal tem mania de ficar atrás da gente. Quando o fiscal chegava perto ninguém denunciava, falava que tava tudo bem... Eu saía de perto dos fiscais, via que tinha formiga na comida deles... Aí eu comecei a ir na hora do almoço, porque além de eu presenciar... eu via também... Eu ia no serviço, eu ia no alojamento, eu via aqueles que tava doentes, que não tinham ido. Ia no posto de saúde; descobri que tinha um remédio pra dor pra tudo, tinha uns comprimidinhos brancos lá que era pro cortado, pra dor de cabeça, pra dor de barriga, pra tudo. O mesmo remédio! Depois eu descobri que tinha os remédios do SUS [Sistema Único de Saúde], que tinha direito a ter os remédios do SUS, que esse comprimido branco lá era cobrado dos trabalhadores. Aí briguei pelo remédio do SUS, que a gente tinha direito ao remédio do SUS e eu consegui levar o remédio do SUS pra lá, aí descobri que o remédio do SUS tava sendo cobrado, também. Foi isso que me levou a descobrir que eles estavam fazendo uma água parecida com um suco, eles tinham água tratada lá para eles, mas os trabalhadores, não! Estes não tinham acesso à água tratada. Porque quando o Ministério do Trabalho chegou lá, com o grupo móvel de fiscalização, tiveram que mostrar. Mas os trabalhadores estavam bebendo uma água horrível, parecia suco de tão suja a água, nojenta! A mesma água que eles tomavam banho, eles bebiam.

17 "Reflexões sobre violência, política e trabalho no campo", correspondência pessoal (ver nota anterior). 
Ainda chegou comida estragada, eu vi que não tinha como! Eu fazia ofício, reivindicava [...] Não havia água suficiente, não dava pra eles, tinha muito peão, mais de mil! [em época de corte da cana, mais de 4000 trabalhadores] Então não forneciam água suficiente, no máximo levavam uma botijinha para o serviço [...] Eu pegava denúncia... Não punha o nome de quem tinha reivindicado... Fazia uma reivindicação por todos, foi indo, nem eles queriam mais assinar meu ofício. Aí eu optei por chamar o ministério para me ajudar, fiz uma denúncia, em maio de 2005, à unidade móvel do Ministério do Trabalho. Aí eles vieram, passaram um mês... três meses! Aí visitou, deram uma olhada nas fazendas aí tudo... Tinha denúncia de trabalho escravo... Denunciei tudo que eu tinha direito! Todos aqueles que, os mais bandidos da região, denunciei tudo! Se eu aparecer morta aí, não sei quem matou. Vou morrer sem saber quem matou... (risos). A mais problemática, em primeiro lugar a Gameleira, foi campeã em número. Desrespeito total! Lá existiam 1200 trabalhadores, só na área rural, sem contar das outras áreas que não é da minha categoria. Que eu ajudo também, nós temos o grupo dos direitos humanos, do padre Alex. Quando não é da minha categoria, para não complicar, parto para os direitos humanos.

Depois de tentar todas as negociações com a destilaria para mudar as condições de trabalho, ela percebeu que a situação exigia a presença do Ministério do Trabalho; já podia contar, naquele momento, com uma ação política mais eficiente do Estado para atender tais reivindicações: auditores fiscais do Ministério do Trabalho e Emprego, agentes e delegados da Polícia Federal e procuradores do Ministério Público do Trabalho integram os grupos. E, é bom lembrar, o país havia lançado, em março de 2003, um Plano Nacional para a Erradicação do Trabalho Escravo (Sakamoto, 2005b). Dessa forma, Aparecida lançava-se legitimada para representar os trabalhadores, obter o seu reconhecimento e, na prática cotidiana, aprendeu a lidar com os fiscais da Gameleira: intrometia-se em tudo, misturava-se com os trabalhadores, perguntava, olhava tudo - descobriu os remédios que eram ilegalmente vendidos -, ia a todos os lugares e confundia rapidamente os fiscais. Não teve dúvidas, acionou o Ministério do Trabalho, o grupo móvel de fiscalização (que foi acompanhado da Polícia Federal), consciente dos riscos que aquele enfrentamento gerava. Ao expor a situação ilegal em que se encontravam os trabalhadores na Gameleira, denuncia o trabalho análogo a de escravo: 
A Gameleira traz esses trabalhadores aí, eles têm preferência pelo pessoal do Nordeste, porque aqui o fllho chora e a mãe não vê, faz de conta que tá tudo bonitinho lá na terra deles, o contrato com o Ministério do Trabalho que trazem no papel não tem coisa mais linda, mas aí chega aqui eles deitam e rolam, se não tiver alguém... E aqui já morreu gente, já foi gente torturada! [...] O trabalhador reivindica e reclama da comida, casa, água... suja! Comida estragada e pouca, e maus tratos e mau pagamento. Muitos maus tratos. Trabalho escravo! Existe uns escravos contemporâneos, ainda, que apanham até hoje, com corrente de motosserra, menos do que naquele tempo, mas ainda existe. [...] Tem trabalho escravo nessas fazendas, porque quando o trabalho é muito degradante é considerado trabalho escravo. Nem que eu tenha o direito de ir e vir, muitos como os nordestinos que não têm acesso... Eles dizem que não é escravo porque tem o direito de ir e vir. De que adianta eu falar pra você ir embora, quando você não foi pago, não tem casa ou não tem um centavo pra ir embora pro Maranhão ou outra parte do Nordeste, que é o caso de Alagoas, Pernambuco, do Ceará! Se tem direito, mas não tem acesso... Eu considero que o trabalhador... Um trabalho muito degradante. Onde ele tá comendo comida estragada, água suja, tomando água suja, num alojamento que não era digno e tinha maus tratos... Eram seis centavos por metro de corte de cana, ninguém tava conseguindo passar os 70 metros por dia, se eles tirassem 100 metros por dia eles ganhariam seis reais por dia. Ainda pra descontar o kit do café, o almoço, o jantar e o transporte... Sobra o quê? Tinham muitos trabalhadores nessa condição... Tinha aqueles bem fortes e novos, que chegavam a fazer até 150 metros por dia, que era uma raridade. Mas aquelas pessoas se arrebentavam pra tirar dez reais por dia, ficavam doentes. Aquelas pessoas mais idosas, aquelas pessoas que não tinham o físico tão preparado, tiravam seis reais por dia, ainda cativo, porque se fosse livre, seis reais não era nada ainda.... Ainda cativo...

Aparecida cadencia suas informações sobre as condições de trabalho na Gameleira, com a designação "trabalho escravo"! E, no final dessa parte da entrevista, introduz a expressão: “Ainda cativo!” O que propicia enfatizar a sua argumentação e ir produzindo o significado combativo que se deseja: ali se configura a prática de trabalho escravo, pelas condições degradantes que no que tange à alimentação, à saúde e à moradia do trabalhador; além dos maus tratos, das torturas, das mortes. Há ainda a se considerar os excessos 
criminosos da jornada e da quantidade de trabalho, que associam a sorte, a má sorte, de velhos e jovens e, praticamente, os iguala. ${ }^{18} \mathrm{~A}$ linguagem de Aparecida é também sua arma, que salta, desloca e emite detalhadas análises e avaliações. Legitima o nome, trabalho escravo, trabalho cativo, tática do combate. No primeiro momento, em que armou as denúncias contra a Gameleira, conta que o "Ministério do Trabalho ficou três meses na região" e fiscalizou não só a Gameleira, mas várias fazendas, com base em diversas denúncias de trabalho escravo que fez, até mesmo fora do município de Confresa. Foi um trabalho muito bonito na região toda, ela diz.

Assim, a ênfase no relato oral e na ação prática de Aparecida, que tem como referência os trabalhadores em condições de trabalho escravo, torna-se fundamental na produção desse acontecimento. A fim de não se congelarem termos e palavras, entende-se sua força política mobilizadora, específica das situações históricas deste tempo presente. Não há exploração que não opere sua inscrição sobre corpos. E nesses corpos, inscreve-se o trabalho escravo. É por isso que estamos diante de um acontecimento que marca presença como "uma mobilização política na conquista de um direito", para usar as palavras do antropólogo Alfredo W. B. de Almeida (2009, p. 69).

Contemplando, ainda, o entendimento ético-legal do problema, o coordenador da Campanha Nacional da CPT contra o Trabalho Escravo, Xavier Plassat (2010, p. 90), diz:

[...] a partir das evidências trazidas pela fiscalização, o legislador brasileiro torna mais explícitas, por lei aprovada em dezembro de 2003, as figuras concretas do crime de trabalho (análogo ao de) escravo: negação da liberdade do trabalhador (o trabalho forçado) e violação da sua dignidade (o trabalho degradante) passam então a tipificar com clareza o crime descrito no artigo 149 do Código Penal Brasileiro.

Entretanto, Aparecida, muito pontualmente, adverte: "o direito de ir e vir" não é mais definidor da condição de liberdade: "Nem que eu tenha o direito de ir e vir, de que adianta eu falar pra você ir embora se você não tem

18 "A prática do trabalho escravo no Brasil, principalmente na região de fronteira agrícola amazônica, revela uma situação de extrema vulnerabilidade e miséria. Os trabalhadores libertados, na grande maioria dos casos, são homens na faixa dos 18 aos 40 anos, que deixam sua terra, principalmente de estados como o Maranhão e o Piauí, na expectativa de encontrar trabalho em outro lugar." (Sakamoto, 2005b, p. 42). 
casa ou não tem um centavo pra ir embora pro Maranhão ou outra parte do Nordeste, de Pernambuco, do Ceará! Eu tenho direito, mas não tenho acesso..." O corpo, inscrito com as marcas do trabalho escravo, para ela, torna o trabalhador um "cativo"; palavra que Aparecida, nessas situações, lança no campo da luta, e devolve aos proprietários e ao Estado. O corpo desfeito opera outra linguagem, e denuncia que o corpo produtivo tornado improdutivo exige direitos, e a omissão dos proprietários deve, também, ser criminalizada. Desenha-se, nesse quadro da narrativa oral de Aparecida, um novo modo de usar a linguagem, um funcionamento diferente de seu uso no campo da luta pelos direitos dos trabalhadores; traçou com as mãos e esboçou, com sua narrativa oral, uma parte da história do trabalho e do trabalho escravo contemporâneo. Sim, do trabalho escravo! Ela diz.

Como uma artista no universo dos saltimbancos, finalizo este artigo com as suas palavras, para continuar a pensar para além das linhas aqui escritas: "Também sou do grupo dos direitos humanos. Quando é no campo, sou do sindicato rural e quando o caso é daqui da cidade (muitos trabalhadores não têm sindicato da sua categoria...), eu faço um ofício-denúncia como membro [do grupo] dos direitos humanos".

\section{Referências}

ABREU E LIMA, M. S. Construindo o sindicalismo rural: lutas, partidos, projetos. Recife: Oito de Março, 2005.

ACIOLI, V. L. C.; ASSIS, V. M. A. de. A justiça e o direito como estratégia de resistência ao trabalho escravo em Pernambuco. In: MONTENEGRO, A.; GUIMARÃES NETO, R. B.; ACIOLI, V. (Org.). História, cultura, trabalho: questões da contemporaneidade. Recife: Ed. da UFPE, 2011. p. 58-70.

ALBERTI, V. História oral: a experiência do CPDOC. Rio de Janeiro: Fundação Getúlio Vargas, 1990.

. "Narrativas pregnantes" como jogos de linguagem: possibilidades da história oral à luz da teoria de Wittgenstein. História Oral: Revista da Associação Brasileira de História Oral, v. 11, n. 1-2, p. 127-148, jan./dez. 2008.

ALMEIDA, A. W. B. de. Povos e comunidades tradicionais atingidos por conflitos de terra e atos de violência. In: CONFLITOS no campo 2009/CPT. Coordenação: Antonio Canuto, Cássia Regina da Silva Luz, Isolete Wichinieski. São Paulo: Expressão Popular, 2010. p. 64-72. 
ALMEIDA, A. W. B. de. Antropologia dos archivos da Amazônia. Rio de Janeiro: Casa 8: Fundação Universidade do Amazonas, 2008.

BARROS, M. de. Gramática expositiva do chão. Rio de Janeiro: Civilização Brasileira, 1990.

BARROZO, J. C. Os assentados e os assentamentos rurais do Araguaia. In: HARRES, M.; JOANONI NETO, V. História, terra e trabalho em Mato Grosso: ensaios teóricos e resultados de pesquisas. São Leopoldo: Oikos: Unisinos; Cuiabá: EDUFMT, 2009. p. 90109.

BARROZO J. C. et al. (Org.). Mato Grosso: do sonho à utopia da terra. Cuiabá: EdUFMT: Carlini\&Caniatol, 2008.

BENJAMIN, W. Sobre o conceito de história. In: BENJAMIN, W. Obras escolbidas: magia e técnica, arte e política: vol. I. São Paulo: Brasiliense, 1985. p. 222-232.

CASALDÁLIGA, P. Uma Igreja da Amazônia em conflito com o latifúndio e a marginalização social. São Félix do Araguaia, 10 out. 1971. Carta pastoral. Disponível em: <http://www. servicioskoinonia.org/Casaldaliga/cartas/1971CartaPastoral.pdf>. Acesso em: 10 nov. 2010.

CERQUEIRA, G. C. et al. (Org.). Trabalho escravo contemporâneo no Brasil: contribuições críticas para sua análise e denúncia. Rio de Janeiro: Editora da UFRJ, 2008.

COMISSÃO PASTORAL DA TERRA. Conflitos no campo, Brasil-2009. Goiânia, 2010.

DABAT, C. R. Moradores de engenho: relaçóes de trabalho e condições de vida dos trabalhadores rurais na zona canavieira de Pernambuco segundo a literatura, a academia e os próprios atores sociais. Recife: Editora Universitária da UFPE, 2007.

DEL CASTILLO TRONCOSO, A. Conceptos, imágenes y representaciones de la niñez en la ciudad de México (1880-1920). México: El Colegio de México/Instituto de Investigaciones Doctor José María Luis Mora, 2006.

DELEUZE, G. Proust e os signos. Rio de Janeiro: Editora Forense-Universitária, 1987.

DELGADO, L. de A. N. História oral: memória, tempo, identidade. 2. ed. Belo Horizonte: Autêntica, 2010.

DUARTE, G. R.; KRAMER, M. F.; LAVERDI, R. (Org.). História, práticas culturais e identidades: abordagens teórico-metodológicas. Cascavel: Edunioeste, 2009.

ESTERCI, N. Conflito no Araguaia: peões e posseiros contra a grande empresa. Petrópolis: Vozes, 1987.

. Escravos da desigualdade: estudo sobre o uso repressivo da força de trabalho hoje. Rio de Janeiro: Cedi: Koinonia, 1994. 
FARIA, R.; MONTENEGRO, A. T. (Org.). Memória de professores: histórias da UFMA e outras histórias. São Luís: UFMA/Departamento de História; Brasília: CNPq, 2005.

FERREIRA, E. de C.; FERNÁNDEZ, A. J. C.; SILVA, E. P. da. A reconstrução dos assentamentos rurais em Mato Grosso. In: MEDEIROS, L. S. de; LEITE, S. (Org.). $A$ formação dos assentamentos rurais no Brasil: processos sociais e políticas públicas. Porto Alegre: UFRGS; Rio de Janeiro: CPDA, 1999. p. 197-231.

FERREIRA, M.; AMADO, J. (Org.). Usos e abusos da história oral. Rio de Janeiro: Editora da Fundação Getúlio Vargas, 1996.

. Histórias de família: casamentos, alianças e fortunas. Rio de Janeiro: Léo Christiano Editorial, 2008.

FIGUEIRA, R. R. Pisando fora da própria sombra. Rio de Janeiro: Civilização Brasileira, 2004 .

FUNES, E. A. Mocambos: natureza, cultura e memória. História Unisinos, v. 13 n. 2, p. 146 153, maio/ago. 2009.

. Resistência e africanidade na Amazônia brasileira. In: FUNES, E. A. et al. (Org.). África-Brasil-Portugal: história e ensino de história. Fortaleza: Editora da UFC, 2010. v. 1, p. 94-126.

FUNES, E. A. et al. História e memória das três fronteiras: Brasil, Peru e Bolívia. São Paulo: Educ, 2009.

GOMES, A. de C. (Org.) Escrita de si, escrita da história. Rio de Janeiro: Fundação Getúlio Vargas, 2004.

. A invenção do trabalhismo. 3. ed. Rio de Janeiro: FGV, 2005.

. Direitos e cidadania: memória, política e cultura. Rio de Janeiro: FGV, 2007a.

. Ministério do Trabalho: uma história vivida e contada. Rio de Janeiro: CPDOC, 2007b.

. Trabalho análogo a de escravo: construindo um problema. História Oral: Revista da Associação Brasileira de História Oral, v. 11, n. 1-2, p. 11-41, jan./dez. 2008.

GOMES, A. de C.; PESSANHA, E. Memória da Justiça do Trabalho: trajetórias de juízes. Porto Alegre: AlegrePOA: TRT4, 2010.

GRACIA, G. N. Después de vivir un siglo: ensayos de historia oral. México: INAH, 2005.

GUIMARÃES NETO, R. B. A lenda do ouro verde: política de colonização no Brasil contemporâneo. Cuiabá: Unicem (Apoio Unesco), 2002 
GUIMARÃES NETO, R. B. Memória, relatos e práticas de espaço: cidades em áreas de ocupação recente na Amazônia (Mato Grosso, 1970-2000). História Oral: Revista da Associaçãoo Brasileira de História Oral, v. 9, n. 1, p. 49-68, jan./jun. 2006.

. Mundo do trabalho. Mato Grosso: cidades, vilas e outras áreas entre o urbano e o rural. In: HARRES, M.; JOANONI NETO, V. (Org.). História, terra e trabalho em Mato Grosso: ensaios teóricos e resultados de pesquisas. São Leopoldo: Oikos: Unisinos; Cuiabá: EDUFMT, 2009. p. 66-89.

HARRES, M. Pelos caminhos da memória: uso de fontes orais na pesquisa histórica. In: HARRES, M.; JOANONI NETO, V. (Org.). História, terra e trabalho em Mato Grosso: ensaios teóricos e resultados de pesquisas. São Leopoldo: Oikos: Unisinos; Cuiabá: EDUFMT, 2009. p. 13-25.

HEYMANN, L. O devoir de mémoire na França contemporânea: entre memória, história, legislação e direitos. In: GOMES, A. de C. (Org.). Direitos e cidadania: memória, política e cultura. Rio de Janeiro: FGV, 2007. p. 15-44.

JAMES, D. História de vida, memória e identidade política. In: CONFERÊNCIA e palestras do X Encontro Nacional de História Oral. Apresentação gravada. Recife: UFPE, 2010. 1 DVD.

JANOTTI, M. de L. O livro Fontes históricas como fonte. In: PINSKY, C. B. (Org.). Fontes históricas. São Paulo: Contexto, 2005. p. 9-22.

. A incorporação do testemunho oral na escrita historiográfica. In: CONFERÊNCIA e palestras do X Encontro Nacional de História Oral. Apresentação gravada. Recife: UFPE, 2010. 1 DVD.

JOANONI NETO, V.; CASTRAVECHI, L. A. Da histórica dominação sobre vidas prescindíveis. As muitas faces da violência sobre trabalhadores migrantes no nordeste de Mato Grosso do final do século XX. In: HARRES, M.; JOANONI NETO, V. (Org.). História, terra e trabalho em Mato Grosso: ensaios teóricos e resultados de pesquisas. São Leopoldo: Oikos: Unisinos; Cuiabá: EDUFMT, 2009. p. 110-128.

LE BRETON, B. Vidas roubadas: a escravidão moderna na Amazônia brasileira. São Paulo: Loyola, 2002.

LIMA, M. do R. S. Uma bistória de luta e resistência entre fazendeiros e sertanejos, no povoado Beira do Rio (Porto Alegre do Norte), décadas de 1960 a 1970. Monografia. (Graduação em História)-Curso de História, Universidade do Estado do Mato Grosso, Cáceres, 2002.

LUCA, T. R. de. História dos, nos e por meio dos periódicos. In: PINSKY, C. B. (Org.). Fontes históricas. São Paulo: Contexto, 2005. p. 111-153.

MAIA, A. C. N. Encontros e despedidas: história de ferrovias e ferroviários de Minas. Belo Horizonte: Argumentum, 2009. 
MAUAD, A. M.; GOMES, A. de C. (Org.). Memória: imigração espanhola em Niterói. Niterói: Niterói Livros, 2006. v. 1.

MAUAD, A. M.; KNAUSS, P. Memória em movimento: a experiência videográfica do LABHOI. História Oral, v. 9, n. 1, p. 143-158, jan./jun. 2006.

MONTENEGRO, A. T. História oral e memória: a cultura popular revisitada. 4. ed. São Paulo: Contexto, 2002.

. História, metodologia, memória. São Paulo: Contexto, 2010.

MONTENEGRO, A. et al. História oral e memória: a cultura popular revisitada. 4. ed., São Paulo: Contexto, 2002.

- História, cultura e sentimento: outras histórias do Brasil. Recife: Editora Universitária da UFPE; Cuiabá: Editora da UFMT, 2008.

MONTENEGRO, A.; GUIMARÃES NETO, R. B.; ACIOLI, V. (Org.). História, cultura, trabalho: questões da contemporaneidade. Recife: Ed. da UFPE, 2011.

MONTYSUMA, M. Um encontro com as fontes em História Oral. Estudos IberoAmericanos, v. 32, n. 1, p. 117-125, jun. 2006.

NASCIMENTO, F. A. do; MONTE, R. (Org.). Cidade e memória. Teresina: EDUFPI, 2009.

OLIVEIRA, A. U. de. A fronteira amazônica mato-grossense: grilagem, corrupção e violência. Tese (Livre docência)-Departamento de Geografia da Faculdade de Filosofia, Letras e Ciências Humanas, Universidade de São Paulo, São Paulo, 1997.

PEDRO, J. M. Estudos de gênero, política e testemunho: a contribuição da História Oral. In: CONFERÊNCIA e palestras do X Encontro Nacional de História Oral. Apresentação gravada. Recife: UFPE, 2010. 1 DVD.

PEREIRA, A. dos R. A Igreja Católica, o Sindicato dos Trabalhadores Rurais e o Estado: mediação e conflito na região Araguaia Paraense. Ruris, v. 2, n. 2, p. 99-136, set. 2008.

PEREIRA, A. dos R. Conflitos de terra e violência no sul do Pará (1975-1990). In: CONFERÊNCIA e palestras do X Encontro Nacional de História Oral. Apresentação gravada. Recife: UFPE, 2010. 1 DVD.

PLASSAT, X. Erradicação do trabalho escravo? Ficou para outra vez. In: CONFLITOS no campo, Brasil-2005. Goiânia: Comissão Pastoral da Terra, 2006. p. 146-151.

. Trabalho escravo: 25 anos de denúncia e fiscalização. In: CONFLITOS no campo 2009/CPT. Coordenação: Antonio Canuto, Cássia Regina da Silva Luz, Isolete Wichinieski. São Paulo: Expressão Popular, 2010. p. 90-100. 
PORTELLI. A. Sempre existe uma barreira: a arte multivocal da história oral. In: PORTELLI. A. Ensaios de história oral. São Paulo: Letra e Voz, 2010. p. 11-35.

PORTO-GONÇALVES, C. W. Amazônia, Amazônias. São Paulo: Contexto, 2001.

. Geografia da violência no campo brasileiro: o que dizem os dados de 2003. Revista Critica de Ciências Sociais, v. 75, p. 139-169, 2006a.

. A globalização da natureza e a natureza da globalização. Rio de Janeiro: Civilização Brasileira, 2006b.

PORTO-GONÇALVES, C. W.; ALENTEJANO, P. R. R. A violência do latifúndio moderno-colonial e do agronegócio nos últimos 25 anos. In: CONFLITOS no campo 2009/ CPT. Coordenação: Antonio Canuto, Cássia Regina da Silva Luz, Isolete Wichinieski. São Paulo: Expressão Popular, 2010. p. 109-118.

POZZI, P. "Era como una droga escucharlo a Perón". Recordando la militancia treinta años más tarde (1955 a 1976). Clio: Série História do Nordeste, n. 28.1, 2010.

PRADO, A. A. (Coord.). Terra e trabalho escravo, violência e impunidade. Niterói: UFFCentro de Estudos Sociais Aplicados, 2002.

SAKAMOTO, L. Lucro fácil, mão-de-obra descartável: a escravidão contemporânea e a economia internacional. In: COGGIOLA, O. (Org.). América Latina e a globalização. São Paulo: FFLCH/PROLAM/Universidade de São Paulo, 2004. p. 257-269.

. Os compadres da casa-grande. In: CONFLITOS no campo, Brasil-2004. Goiânia: Comissão Pastoral da Terra, 2005a. p. 118-123.

. (Coord.). Trabalho escravo no Brasil do século XXI. Brasília: Organização Internacional do Trabalho, 2005b. Disponível em: <http://www.oitbrasil.org.br/ download/sakamoto_final.pdf>. Acesso em: 10 nov. 2010.

SANT’ANA, D. A. B. Alianças multifacetadas: colonização de Juara, discursos, práticas culturais e memórias (1971-2008). Dissertação (Mestrado em História)-Instituto de Ciências Humanas e Sociais, Universidade Federal do Mato Grosso, Cuiabá, 2009.

SANTOS, M. A natureza do espaço: técnica e tempo: razão e emoção. São Paulo: Hucitec, 1996.

SARLO, B. Tempo passado: cultura da memória e guinada subjetiva. São Paulo: Companhia das Letras; Belo Horizonte: UFMG, 2007.

SCHMIDT, B. B. Do que falamos quando empregamos o termo "subjetividade" na prática da história oral?. In: ENCONTRO REGIONAL SUL DE HISTÓRIA ORAL, 5., 2009, Marechal Cândido Rondon. Texto apresentado na mesa-redonda História Oral, Memória e Subjetividades. 
SILVA, I. S. Serra Nova Dourada, MT. Confresa: Parceladas, 2006.

SMITH, R. C. História oral e historiografia nos Estados Unidos: impasses e problemas. In: CONFERÊNCIA e palestras do X Encontro Nacional de História Oral. Apresentação gravada. Recife: UFPE, 2010. 1 DVD.

SOARES, L. A. Nas trilhas da memória. Dissertação (Mestrado em História)-Instituto de Ciências Humanas e Sociais, Universidade Federal do Mato Grosso, Cuiabá, 2004.

SOUZA, M. A. M. Retalhos de vidas: escravidão contemporânea nas agropecuárias do Araguaia (1970-2005). Dissertação (Mestrado em História)-Instituto de Ciências Humanas e Sociais, Universidade Federal do Mato Grosso, Cuiabá, 2009.

. A luta pela permanência na terra: a resistência dos posseiros de Santa Terezinha década de 1970. Monografia. (Graduação em História)-Curso de História, Universidade do Estado do Mato Grosso, Luciara, 2002.

VIEIRA, M. A. da C.; ESTERCI, N. Trabalho escravo no Brasil: os números, as lutas e as perspectivas em 2003. In: CONFLITOS no campo, Brasil-2003. Goiânia: Comissão Pastoral da Terra, 2004. p. 137-152.

WITTGENSTEIN, L. Investigações filosóficas. São Paulo: Abril Cultural, 1979. (Os Pensadores).

Resumo: Este artigo focaliza o tema do trabalho no Brasil contemporâneo, na região que se convencionou designar de Amazônia Legal. O fio condutor da análise é a narrativa oral da presidenta do Sindicato dos Trabalhadores Rurais da cidade de Confresa (MT), Aparecida Barbosa da Silva. Esta atua em uma das áreas de maior incidência de conflitos trabalhistas da Amazônia, espaço predominante do agronegócio exportador, onde se destacam a utilização e práticas de "trabalho análogo a de escravo". O relato de Aparecida Barbosa da Silva abre outras perspectivas de análise, por não se limitar a apresentar denúncias contra o direito dos trabalhadores pobres, mas, em especial, porque revela a importância da narrativa oral como uma prática discursiva que interfere, modifica e atua na configuração da luta como afirmação dos direitos dos trabalhadores.

Palavras-chave: história, narrativa oral, trabalho, violência.

History, politics, testimony: violence and labour in the Brazilian Amazon. The oral narrative of the president rural workers' union in the city of Confresa (MT), Aparecida Barbosa da Silva

Abstract: This article focuses on the theme of labour in contemporary Brazil, in the region that was agreed to be designated as the Legal Amazon. The analyses are based on oral narrative of the President of the Union of Rural Workers in the city of Confresa, MT, Aparecida Barbosa da Silva. She works in an area which has one of highest rates of work conflicts in the Legal Amazon, a predominant area of agribusiness exporter, which highlight the use and practice of 
'labor conditions analogous to slavery'. The oral narrative of Aparecida Barbosa da Silva expands to other perspectives of analysis due to the fact that it is not limited to denouncing violations to the workers' rights, and, especially, because it reveals the importance of the oral narrative as a discursive practice which interferes, modifies and acts upon the configuration of the struggle as the affirmation of the workers' rights.

Keywords: history, oral narrative, labour, violence.

Recebido em 01/12/2010

Aprovado em 05/01/2011 